\title{
Language-learner tourists in Australia: Problematizing 'the known' and its impact on interculturality
}

\author{
Phiona Stanley \\ phiona.stanley@unsw.edu.au
}

Please cite as: Stanley, P. (2014). Language-learner tourists in Australia: Problematizing

'the known' and its impact on interculturality. In D. J. Rivers (Ed.) Resistance to the

known in foreign language education (pp.23-46). Basingstoke: Palgrave Macmillan.

\section{Introduction}

Think of 'typical' Australian scenes, and what springs to mind? Likely images include blond surfers on sun-drenched beaches, indigenous faces patterned with paint, Sydney opera house, cricket and rugby, dangerous wildlife and outback terrain, and curious marsupials. All of this is 'true' in that it does exist, and all of it is 'authentic' in that such images do lie (pun intended) in Australian history, popular culture, fauna, and geography. But such images are also manufactured by the tourism industry and by social imaginaries, both inside and outside Australia. And when language education intersects strongly with tourism, as it does in the contexts discussed in this chapter, such images operate as a tyrannical 'known' that shapes the experiences that students imagine, and so expect, from their Australian sojourn. Language education providers are then under pressure to provide, indeed to manufacture, Australian 'authenticity' as this is imagined by cultural out-groups: the students and their friends and families back home, to whom the experience is displayed on social media. This chapter considers the impact of this on English language education in contexts particularly affected by this (imagined) 'known': language schools in Australian cities that are very much on tourism's beaten path.

The study was inspired by my reflections on and conversations with other trainers about the training of teachers on Cambridge CELTA courses in Sydney. I noticed that the teachers we thought most capable and that we graded highly against CELTA pass criteria were not necessarily those who found and kept jobs in the local language school sector, and that, conversely, plenty of those who struggled with teaching and analysing language turned out to be the most employable. The reasons for this fell into place somewhat when I started thinking about the complexity of the teaching role in local language-school contexts: part teacher, part cultural insider, part friend, perhaps. I remember doing a one-to-one tutorial with a weak CELTA candidate at risk of failing the course who told me, in dismay, "but the students like me". And they did: he was bubbly and personable and he cared about them, although he struggled to address their language questions and his classroom management was chaotic. He eventually passed CELTA, and found work, and his students still liked him very much. But although he was a good teacher (in the context), he was not a particularly good teacher (in the sense I understand it). The problem is one of naming: he is good at doing the job expected by Australian language schools and their students although he is not particularly technically skilled, as measured by CELTA-type criteria. In fact, a de facto teacher role seems to be operating in the context and this stems, in part, from the tyranny of 'the known' about what Australia, and Australians, are like. 
So I designed a study to understand what students want when they come to Australian language schools to study English, particularly at the 'language travel' end of the market. This was a qualitative, interview-based study and my research questions were as follows: what do students expect/want from their Australian language school experience and what are the effects of these demands on the teachers and on teaching? From this, how might a de facto teacher role be described? From this work, I theorise that the students' demands and expectations coalesce to form 'the known' of out-group imagined 'authenticities', and that these, in turn, form part of the de facto teacher role. This 'known' is constructed mainly by students themselves but perpetuated and in part created by marketing departments and, ultimately, teachers themselves. The notion that 'authentic' Australians are blond, bubbly, fun surfer types goes unchallenged in many classrooms, particularly for short-stay languagetourists. But there is also resistance, and in some contexts students were exposed to the realities of a complex, multi-cultural, socially stratified Australia with its convict history and plenty of indigenous blood on its hands.

\section{Situating this Study in the Literature}

In theoretical and empirical terms, this is a complex study to situate in the literature: there is no single 'field' into which it conveniently fits. It is therefore necessary to cast rather a wider net, and this section draws upon literature from tourism studies and gender studies as well as language education and intercultural studies. It discusses out-group social imaginaries and their role in framing expectations and evaluations of cultural others. From there, the discussion turns to discourses of cultural purity and 'authenticity', and describes the staged authenticity in which tourism providers engage in order to meet tourists' demands for essentialist cultural fixities; I contend that something similar is happening in Australian language schools, where there is a circle of marketing-led, tourism-like imagery that is performed back to students and seldom disrupted, with deleterious effects on students' development of interculturality.

'The known' in this context is an out-group constructed social imaginary about what Australia, and Australians themselves, are like. By 'social imaginary', I mean:

That set of symbols and conceptual frameworks particular to a social collectivity or network, which have been built up, modified, mediated and transformed over time, and which are drawn on in the sense-making process... The imaginary refers to the ways in which a nation or other grouping sees both itself, and others, that is, those considered not part of itself...The media here is understood as a mediator and shaper of that set of projected and shared envisionings. (Lewis, 2009: 227)

This is not to say that a single, homogenous social imaginary exists among potential English language students outside of Australia, and it is important to note that out-group constructions may differ. For example, students interviewed for this study construct Australia and their Australian study sojourn variously as follows:

[Before I arrived] I think teachers here, they are all very motivated...And they are funny. I think it's very important, because you are not in the real school...This is like, it's school, okay, but it's like holidays, it's mixed...It doesn't have to be like high school. We want to take it easy. (Sylvia, Italian student, chain language centre, Regional City, 2012)

First of all I thought, I just wish[ed] that all the teachers have special way to teach English correctly. So once I had a question to my teacher but she can't answer to me. So I'm really disappointed because I didn't expect that situation. So, yes, that was a bit different... In Korea, it's a little bit passive way but they're strict so they always made us to study. But here I think it's cultural things, it's a little bit different...I don't think it's strict enough...For example they don't check my homework. Yes, it's my responsibility but if they check my 
homework every day I would do that. (Hye Jun, Korean student, chain language centre, Regional City, 2012)

When you are in Colombia and somebody speaks with you about Australia, you're only thinking kangaroos, koalas. [They think] there is koalas in Sydney...Before I arrived here I thought that this country was like United States, like a big city, busy city. All the people maybe stressful, maybe angry. But when I arrived here I saw that all the people was very organised, all the things was just very organised...Here people maybe thinking of you if you have a problem, [people ask] "are you okay?" Friendly. (Andrés, Colombian student, independent language centre, State Capital, 2012)

These excerpts evidence the variety of social imaginaries of Australia that exist among incoming students. Whereas Sylvia constructs her Australian experience as part holiday and hopes that her teachers will be fun, funny, relaxed, and energetic/passionate ('motivated'), Hye Jun constructed strict, expert teachers who would ensure quick progress; these images are at odds. Andrés had a different construction altogether, and one that differs from the majority construction that is the title of this chapter: the blond, relaxed surfer stereotype. Perhaps Tourism Australia is less active in Latin America than, for instance, in Europe or East Asia, and the blond-surfer stereotype has not informed social imaginaries there to the same extent. Indeed, social imaginaries of Anglophone 'gringos' in Latin America may be dominated by love-hate notions about the USA (Pratt, 2004; see Rajagopalan, this volume), which Andrés acknowledges as the source of his pre-arrival constructions. It is important to say, therefore, when discussing social imaginaries that those at work in this study are outgroup constructions, plural. So although a dominant social imaginary of Australia does seem to exist among the students, there are also outliers such as those cited above. Importantly, these remind us that social imaginaries are heterogenous.

It is hard to overstate the importance of social imaginaries in framing lived experiences. This was exemplified in my previous research among university students in Shanghai (Stanley, 2013), for whom 'Western' teachers of English are evaluated according to how well, or otherwise, they correspond to Chinese social imaginaries of what 'authentic' Westerners are like. These out-group constructed stereotypes form powerful criteria against which Westerners are evaluated, with the result that the teachers are pressured into performing back to the students a caricature of the fun, outgoing, loud, confident, non-serious, non-expert Westerners that the Chinese social imaginary had constructed.

This can be theorized with reference to the work, on gender roles, of Judith Butler (1990). Performance expectations borne of out-group constructed social imaginaries operate like roles to provide frameworks within which individuals or experiences may or may not 'fit'. So an individual's appearance or behaviour may be critically evaluated as 'typical' or 'atypical', or as (insufficiently) 'authentic', according to out-group constructions about the cultural identification ascribed to the individual. So if students imagine Australians to be blond, blueeyed surfers, they may subsequently evaluate dark-haired, non-surfer Australians as deficient rather than problematizing the stereotypes. Additionally, students may evaluate Australia itself as disappointing if preconceived expectations are not met. In both cases, expectations frame how lived experiences are experienced and evaluated.

Tourism studies has explored this area, considering tourists' search for what they perceive as 'authentic'. MacCannell (2008: 334) sets out two distinct discourses that may variously frame tourists' expectations of foreign cultural 'authenticities': 
The first would be an essentialist, realist ethnographic perspective that believes in authentic primitives and natives frozen in their traditions. And the second is a post-modern, poststructural, non-essentializing, hip version of culture as emergent, as constantly responding to challenge, changing and adapting.

Where tourists imagine, for example, "authentic primitives and natives frozen in their traditions", we can expect them to be disappointed if, for example, they visit the Amazon and, in place of 'authentic' natives, they find people wearing jeans, using iPads, and drinking lattes. Instead of problematizing their own 'authenticity' constructions it may be easier to critique the natives as lacking. So tourists' experiences may be marred by seemingly inauthentic performances of local people that are evaluated against tourists' own constructions of local cultures (Ateljevic \& Doorne, 2005; Badone \& Roseman, 2004; Kontogeorgopoulos, 2003; Little, 2004; Oakes, 2006; Robinson \& Phipps, 2005; Rojek \& Urry, 1997; White, 2007).

But cultural authenticity is a chimera. No culture is untouched; no culture exists in a vacuum of fixed authenticity - and if it did, it would anyway likely differ from out-group constructions of what that authenticity was actually like. However, MacCannell's (2008) existentialist first discourse of culture still frames many tourists' expectations, and as a result tourism providers may 'stage authenticity'. For instance, Bruner (2005) describes Masai dance performances for tourists in Kenya. Crang (1997: 148) describes such work, of playing expected roles, as "the deep acting of emotional labour". He analyses different types of tourism performances, including ever-smiling airline staff and compulsorily bubbly, chatty, and flirty bar staff in Mediterranean resorts, and concludes that "these employees' selves become part of the product...their personhood is commodified" (Crang, 1997: 153). However, it is more than just employees' performances that are commodified by these jobs. Their ascribed characteristics - ethnicity, gender, age, and looks, for example- are "part of what is required from an employee" (Crang, 1997: 152). So in the same way as 'Western' teachers in China experience pressure to perform back to students the students' own imagined constructions of 'authentic' Western behaviours and characteristics, Australian teachers and home-stay families may be under pressure to live up to incoming languageschool students' expectations, and some providers may choose to 'stage' this 'authenticity' back to students by employing teachers or home-stay families that do not disrupt students' out-group social imaginaries of 'authentic' Australianness.

What is the effect of this, though, on students' interculturality? This is defined as:

The capacity to experience cultural otherness and to use this experience to reflect on matters which are normally taken for granted within one's own culture and environment...in addition, interculturality involves using this heightened awareness of otherness to evaluate one's own everyday patterns of perception, thought, feeling and behaviour in order to develop greater self-knowledge and self-understanding. (Barrett, 2008: 1-2)

While most students in this study stated their primary purpose in Australia as learning or improving their English, most also contextualized this against extrinsic motivations rooted in imagined globalized professional futures and the fostering of transnational identities: in learning English, students hoped to become more employable and more 'global'. And, indeed, the aim of teaching 'culture' along with language is not new. Plenty of scholars have noted the importance of developing learners' interculturality as a goal of language education. But where out-group cultural constructions are not problematized, and indeed, may be reified, by border-crossing experiences, students' interculturality may not develop as anticipated. Young, Sachdev, and Seedhouse (2009: 149) critique the superficial use of culture as context rather than content in language education, concluding that "culture is not approached in the classroom in a principled, active and engaged manner and...this lack of 
engagement may have a detrimental effect on learning". This is a 'food and festivals' view of culture, common in language textbooks, which Holliday (2009: 146) critiques as: "traditional attempts at multiculturalism which have ritualised the sharing of superficial national and ethnic cultural exotica". It appears, then, that we are not teaching culture well, and that much classroom teaching of culture is superficial.

This seems incredibly wasteful of the opportunities presented by transnational educational contexts, like the language schools discussed in this chapter, in which students travel half way around the world to immerse themselves in another culture. In particular, while many students' express purposes include "the internationalization of themselves" (Lisa, Director of Studies, university language centre, Regional City, 2012), language schools could do a much better job of mediating students' interculturality development. It is therefore suggested in this chapter that one immediate solution, already underway in some contexts, is to scaffold students' intercultural learning by engaging critically, in class and elsewhere, with implicit discourses of cultural 'authenticity' which operate in this context as problematic but largely unproblematized 'knowns'. This is the resistance needed to disrupt what is, currently, an 'intercultural' situation that tends to reify rather than challenge pre-existing socially imagined 'authenticities' of essentialist cultures.

\section{Methodology}

This is a qualitative study based on semi-structured interviews with students, teachers, directors of studies, CELTA trainers, and marketing staff at 11 language schools in three Australian cities. The language schools varied in type and included four independent language schools, four language schools belonging to international chains, and three language centres attached to universities. Each of the three 'types' of schools were studied in each of three cities which, for the sake of anonymity, are described here rather than named. The first city is a small regional city, with a population under 200,000. It is firmly on the backpacker tourist trail and its attractions are primarily nature-related. The second city is a state capital with galleries, sporting events, and a buzzing CBD: it feels like a 'proper' city without being too overwhelming, and there are fewer language schools and fewer international students than in the bigger cities and its population is over a million. The third site is one of Australia's 'world cities': hugely multicultural and with a population over four million, it has sprawling suburbs, a complex public transit system, and many thousands of international students.

I gathered a lot of data for this project, and the transcribed interview texts, combined, run to around 200,000 words. I interviewed 70 people, including 37 students, 11 teachers, 13 directors of studies, and seven CELTA trainers. To protect anonymity I have used pseudonyms and blurred identifying details throughout. The students were in their early 20s, and their nationalities included the following: Colombian, Mexican, Belgian, Swiss, German, Korean, Japanese, Italian, Thai, French, and Slovak. Most of the teachers were Australian, whether by birth or naturalization, and while most were native English speakers there were also teachers for whom English was an additional language. The interviews were audiorecorded with participants' consent and all audio recordings were transcribed and analysed inductively, by hand, using Grounded Theory (Charmaz, 2006).

Most of the students were interviewed in small groups, in English or their first language (in the case of low-English-proficiency, all-Spanish-speaking groups in two locations; my Spanish is CEFR C2 level), and most interviews lasted about an hour. A few students and most of the teachers and other language-school staff were interviewed individually. The 
choice of group or individual interview was expedient as much as anything, as this research had to fit around the available time of the participants. However, in a number of the group interviews there were interesting examples of participants' teasing out issues among themselves, such that I do not feel integrity suffered as a result of being interviewed among peers. Indeed, among the students in particular, group interviews were likely less intimidating than a one-to-one interview with a researcher who, to them, may have seemed like a teacher.

The interview schedules were slightly different for each type of participant and in all the central purpose was to answer the central research questions: what do students expect and want from their Australian language school experience and what are the effects of these demands on the teachers and on teaching? The interview questions evolved as the study progressed, as I brought up recurring, particularly unexpected, themes in search of different perspectives and deeper insights. The data is therefore iterative. What emerged most strongly, as this chapter will show, is the sheer complexity of the teachers' de facto roles and the gulf of difference between it and the CELTA pass criteria (Cambridge ESOL, 2003). This certainly explains the poor correlation, noted in the introduction, between those who excel on CELTA and those who succeed in the industry.

\section{Imagining Australian Authenticities}

The remainder of this chapter deviates slightly from the time-honoured research-paper genre structure of 'findings' followed by 'results'. Instead, I present and discuss the data according to themes emerging from the data itself. Themes emerging from the data, and highly relevant to understanding both the 'known' in this context and resistance to it, include: students' imagined Australian 'authenticities', the pressure that schools and teachers perceive to perform such imagined authenticities back to students, and instances of resistance, where teachers and others attempt to problematize, pluralize, and resist imagined 'authenticities' with a view to recognizing and representing Australian diversity and enhancing students' intercultural competence. This first section begins with students' constructions of Australia.

The following extract from a student focus group exposes some common stereotypes held about Australia by these (respectively) Belgian, Swiss, and German students:

Phiona: Before you came here, what was your picture of Australia?

Mathilde: $\quad$ Sun.

Emilie: $\quad$ Sea.

Sabine: Good-looking surfer boys running around.

Emilie: $\quad$ Nice people, they're all friendly.

Sabine: $\quad$ Like everybody's really relaxed all the time.

Mathilde: $\quad$ Yes...People are really relaxed I think.

Sabine: $\quad$ Compared to cities in Europe...

Emilie: $\quad$ Yes.

Sabine: $\quad$ Everything's really relaxed here. In Europe everybody's stressed all the time.

(Students, 'focus group', chain language centre, Regional City, 2012)

These views were typical of the students' pre-arrival constructions, a view that one Director of Studies attributes to Australian tourism destination marketing:

The [Tourism Australia] advertising campaign, which is the selling of Australia overseas, is full of the blonde, blue eyed, bronzed people who are on surf boards with big smiles. (Julia, Director of Studies, university language centre, State Capital, 2012) 
Beyond images from tourism, some students, particularly East Asians but also South Americans and Europeans, constructed Australia as irrevocably different from their home countries. This included notions of universally friendly, 'relaxed' people, and extended to ostensibly more 'dynamic', 'informal', and 'relaxed' classroom environments (various student focus groups, 2012).

This construction is grounded in notions of essential differences between students' home and host cultures, and the following extract from a Director of Studies interview relates this construction back to the selling of Australia in tourism:

Patty: $\quad$ They view anything [in class] that is quiet as boring, quite often.

Phiona: $\quad$ Although in their own countries, learning is often quite quiet.

Patty: $\quad$ Yes, yes but they don't expect that.

Phiona: $\quad$ So it's a different expectation here?

Patty: $\quad$ I think so.

Phiona: Why's that, do you think?

Patty: I think they come with the idea "I'm not at home anymore, therefore I'm out here and everything is brighter and greener on the other side"...They see Australians as what gets sold through the tourism board.

Phiona: $\quad$ Which is what?

Patty: $\quad$ To them, outgoing, bright, bubbly. And that's what they expect.

(Patty, Director of Studies, independent language centre Regional City, 2012)

The above excerpts suggest that, for students arriving in Australia, there is an expectation of finding the following: "good-looking surfer boys", "blonde, blue eyed, bronzed people" who are "really relaxed", "friendly", and "outgoing, bright, [and] bubbly". Students may have an expectation that they will be "friends with [their] teacher", that they will have "teachers who empathise", and that everything will be "different" and "brighter" than at home. These are keywords from the above extracts, and are ideas that came up repeatedly in the data.

However, students' notions of key differences between Australia and their home countries goes beyond tourism-type images of friendly, bubbly Aussies. Recurring in the data was a related notion, referring specifically to notions of differences in education: students' constructions of friendly and friend-like empathetic relationships between teachers and students:

In my country it's almost impossible to be a friend with a teacher and student because of my culture. But unlike my culture, it's different here. I think it's better because they empathise us. I can easily [talk] about my problem.

(Hyori, Korean student, chain language centre, Regional City, 2012) Hyori describes the empathy she perceives between teachers and students in Australian language schools comparing it to the more formal relationship she perceives between teachers and students in Korea. This theme recurred in many student interviews, with some students describing a mutually respectful teacher-student relationship that they perceive and appreciate in Australia. For instance, comparing her language school experience to her mature-age university student experiences at home, Anja explains:

[The teacher] must be friendly and with open mind. It's for me really important. In my home country, I make my education on the second way...I go back to school and make my returns for going to university [as a mature-age student]. I was 25 when I begin the [university]. And I notice there, what's fantastic is the teacher was young, they're [only?] a bit older [that the students], like here. And the connection or the teaching there was like here. You speak with the teacher and he makes fun with you but you know, okay, now we study. It's like here...it's equal. When the teacher, when he is friendly and when he has open mind and he - it's okay when he have his own opinion, that is good. But it must be possible saying your own opinion as a student. 
(Anja, German student, chain language centre, State Capital, 2012) Anja's interview excerpt is more nuanced that Hyori's, perhaps as Anja has experienced adult education in her home country. As a result, instead of comparing school education at home with adult language education in Australia and attributing perceived differences solely to culture, as Hyori appears to do, Anja is better able to delineate the difference between schooling (in Germany) and adult education (in either Germany or Australia), saying she prefers the ostensible equality between teachers and students in both contexts. Of course, Hyori may be correct: perhaps relationships between teachers and students in adult education in Korea are more formal than in Australia. But in both cases above, the students note that they appreciate the apparent informality, approachability, fun, open-mindedness, and friendliness of Australian teachers in class.

So what happens when students arrive in Australia only to find that these constructions are stereotypes, and that Australia is rather different — more multicultural and less bronzed and blond, perhaps - than they had imagined? What if their teacher is more serious, or less 'fun' than they might have imagined? These excerpts tease out the interplay of students' expectations with their lived experiences, beginning with impressions of Australia generally and then considering students' imagined teachers:

Marie: I know Australia is really multicultural and stuff, I know, but on the other hand my [host] family's from Fiji. It's like: I'm not in Fiji; I want to have the real Australian thing.

Phiona: What's the real Australian thing?

Marie: $\quad$ I think that's the hard thing about Australia. You don't really have your own culture. Your culture is too multicultural.

(Marie, Belgian student, chain language centre, Major City, 2012)

We often have issues with students who say, "I'm staying with a Sri Lankan family", [or], "they're Indian"..."Indians aren't English speakers". You know we're in Australia, which is supposedly a multicultural country, and these are people who speak excellent English...but they're not white. The students are stressed by the fact that they're not with a white [family]. You know, their ideal of what it is to be in an Anglo culture.

(Julia, Director of Studies, university language centre State Capital, 2012)

Phiona: You mentioned the idea of good-looking surfer boys. Is this the picture that people have of Australia?

Sabine: $\quad$ Yes. I think so. Yes.

Phiona: $\quad$ Is it true?

Sabine: $\quad$ No. Because when I arrived my [host family] dad, his son is skinny, white, black hair and I'm sorry but he's ugly. Then my host dad arrived, black hair, and even the neighbours are not [blond]. I didn't see in my suburb. There's no good looking [people]. So the stereotype, I didn't see.

Mathilde: Yes. We have like the stereotype of really big blond guys and when I'm on the bus on my way home they're only Chinese guys.

Emilie: $\quad$ Yes. That's right.

Sabine: $\quad$ Yes so different. Yes.

Mathilde: When I'm on the bus I don't think I'm in Australia, it's like I'm in China.

Emilie: $\quad$ Yes.

Mathilde: $\quad$ Yes but I think, I knew that there were a lot of Asian people [here], but I thought it was more mixed. Because you have like the Chinese suburb, the Japanese suburb and I thought it was mixed. ... You really see, like, there are so many Asian people.

(Students, 'focus group', chain language centre, Regional City, 2012) 
These excerpts describe students' negotiations between an imagined 'Australia', as constructed by out-group stereotypes and arguably perpetuated by tourism advertising, and their lived experiences of staying with host families and in suburbs that breach these stereotypes as people there may be Fijian, Sri Lankan, "Chinese", or simply dark haired and "ugly"! These quotes also point to an important reality, that students' experiences of language travel extend well beyond the classroom, comprising home-stay experiences and gettingaround experiences, as well as encounters in everyday life, part-time jobs (for many longerstay students), and engagement with their peers from myriad countries. For some students, this will be a first experience of living away from the parental home, and for most it represents a first time sojourning abroad.

One expectation that emerges, therefore, is that their teacher will act as a conduit into the local culture: an explainer, an 'insider', a guide. So while students may project imagined Australian 'authenticities' onto their teachers, resulting in stereotypical expectations about teachers' personality and appearance, students may also hope that their teacher will help them understand Australian 'realities' from the teachers' experience. However, there is a necessary conflict here: how are teachers to walk the line between performing students' imagined 'authenticities' back to them while also sharing, exposing, and exploring Australian 'insider' realities? It appears that students want a cultural entry point and insider information, but they do not necessarily want their own stereotypes to be disrupted too much. These excerpts speak to this complex demand:

My favourite teacher is my morning class teacher...He try to make conversation with many classmates and he talk about his private story, it makes me closer.

(Emiko, Japanese Student, independent language centre, Regional City, 2012)

They loved [one of the teachers]...I said, "what was so good about [him]?" They said, "he gave personally. We would often be talking about something and he would personalise it and say, 'when I worked here' or 'when I did this', or 'in my life', for example, 'this happened'. Everything he did felt real, and that's what I liked about it. It wasn't just the textbook."

(Amy, Director of Studies, chain language centre, State Capital, 2012)

[In class, some of the most successful teachers] just talk about say why Australians like meat pies so much. Or what their dad used to do when he was living around here...I think most of [the students] actually do go for it, if they've got the personality to carry it. That's the thing, is that if you're that kind of charismatic person and you can make a story a yarn, spin a yarn and make it entertaining. I think the students...feel like they're learning some aspect of Australian culture.

(Mark, Director of Studies, chain language centre, Regional City, 2012)

I think one of the things that the students here enjoy is the fact that we joke with them a lot. Even though we're their teachers, they're all adults so we, kind of, treat them like equals and we joke with them in the same way that we would joke with our friends...I think that's one of the important things in the teacher/student relationship, here at least.

(Amelia, Teacher, chain language centre, Major City, 2012)

Ulrike: $\quad$ Yes. They do like change our lessons because of us. Last week it was about crime law and [our teacher] told us the whole story about [Lindy] Chamberlain with the dingo. Yes it's like the dingo story is really famous in Australia but we didn't know about it.

Marta: Yes. 
Ulrike: $\quad$ So it's good that we do now... I really want to learn about the culture because in my family I don't learn it. ... [Our teacher], she's like our guide here.

Marta: $\quad$ Yes, I mean for example, when we went to [an art gallery] and I really liked it and it was something new...And next time or today she brings typical Australian food so it's something - yes. I like it because in Europe you don't, you have nothing from Australia.

Ulrike: $\quad$ No. We don't know anything about the culture.

Marta: $\quad$ You just know yes Australia, the capital city is Canberra and...

Ulrike: $\quad$ You know like the normal things you learn in school but not like the inside info.

(German and Slovak students, chain language centre, Major City, 2012)

These quotes exemplify what students seem to want and expect from their teachers: empathy and easy communication, teachers who "give personally" and who let students into the "insider info" and their "real" lives, and teachers who joke and can "spin a yarn". This may explain the disjuncture that I had noticed between those who excel on CELTA, for which language analysis and teaching skills are required (but for which there is no need to give personally or be able to spin a yarn), and those teachers who seem to be most successful in language school classrooms. This suggests that teachers are, to some extent, responding to what students want.

\section{Performing Australian 'Authenticities'}

This is no surprise to Directors of Studies, and the following excerpts show various takes on the situation:

I was really amazed because when I first became a [Director of Studies]. I was expecting- I had some jagged personalities in my staffroom, people who were really quite difficult to be with in the staff room. I did -the first six months- I did a whole round of observations, and they were all absolutely delightful in the classroom. [In the staffroom] they might have been, like, gnarly and yeah, jagged is the best word. Kind of sharp edges. But in the classroom they, kind of, turned on the nice personality.

(Julia, Director of Studies, university language centre, State Capital, 2012)

I think that [as a teacher] you can be very technically skilled, but if you're a grumpy bastard you probably won't get great feedback. You can probably get great feedback without being that technically skilled with some classes. So I think that those sort of human attributes, the affective factors, are probably out there [important] for a lot of students. They're here for a short time and they want to feel that somebody is caring and somebody is interested in them.

(Jason, Director of Studies, university language centre, State Capital, 2012)

We started instituting these leaving surveys [and we improved our student satisfaction rate] ...So I'm really happy about that, but in a way, part of me died in the process. Because the way that you really keep students happy has not been to institute a rigorous academic curriculum with clear academic objectives...It's really to think much more carefully about what customers want and their expectations. Trying to hire teachers who really have that personality. That personality for teaching, their personality carries the class and keeps the people on board.

(Mark, Director of Studies, chain language centre, Regional City, 2012)

These participants frame a similar phenomenon differently: while Julia says she was "amazed" at the difference between the "gnarly" teachers in the staffroom and their in-class "delightfulness", Jason appears to accept that part of the teachers' job is the affective factors that make the students feel cared for. Mark's view is the most nuanced and idealistic: saying 
that "part of me died in the process" he acknowledges the trade off he has had to make between the quality language education ("a rigorous academic curriculum with clear academic objectives") that he would prefer to institute and the need to keep students happy by hiring only teachers with the right kind of "personality for teaching" that keeps the students "on board". This comment speaks of seemingly mutually exclusive teacher traits: technical skills and a non-gnarly personality, or at east the ability and willingness to perform as needed. As Crang (1997: 148-153) describes, though, this is "the deep acting of emotional labour" through which the teachers' "personhood is commodified".

This goes beyond personality, though, with some Directors of Studies consciously hiring teachers who also look the part of imagined, 'authentic' Australians:

[One of our teachers] Marco's got that coolness. He's a soccer player...He's hunky looking. The girls love him. He's married so it's all safe... But that just makes all the girls go goo-goo over him. The boys hang out the front [of the school] and he plays basketball with them... So he's for me a dream type of teacher, where the students love him... [The students say] "Marco is the most wonderful teacher ever". When it comes to photos, when they're leaving, it's, "Marco, Marco", every student that's had him...If Marco was small and nerdy and wore glasses, would [the students'] reaction be the same? I don't know. I think probably not.

(Amy, Director of Studies, chain language centre, State Capital, 2012)

The majority of [teachers] are big booming personalities with smiles. The joker jocular, "hey, look at me" kind of person...big, bubbly- people who could host children's television...There are lots of them. There are lots of them. I think of the more successful teachers where I am and they're all dimply-faced people. Almost like a baby face. You know, the non-threatening face that you see on a baby, with big dimples and kind of maybe lower eyes and big smiles. Almost like a child's face actually.

(Julia, Director of Studies, university language centre, State Capital, 2012)

Beyond the issues discussed in the previous section, of students' disappointment and surprise with Fijian or Sri Lankan host families, or negative evaluations of multicultural Australian ethnoscapes that differ from the Anglo-Aussie stereotypes implicitly promised through marketing materials and imagined as out-group social imaginaries, these quotes speaks of a conscious effort on the part of language teaching operations, and Directors of Studies in particular, to perform back to students, through teacher hiring decisions, both the personality and the appearance that students seem to expect.

This is not to say that Directors of Studies are to blame; those I interviewed stressed the pressure they were under to meet student satisfaction targets. This is, then, a complex pressure coming from students themselves, perpetuated by marketing departments, and all too often insufficiently disrupted by Directors of Studies or teachers themselves, whose jobs are predicated on keeping students happy. It is a circle of certainty in which truth is imprisoned.

\section{Resistance to 'The Known'}

How on earth might this situation be resisted, and even resolved? The good news is that there is some resistance to cultural stereotyping and the performance and perpetuation of imagined authenticities. This section describes some ways in which the circle of certainty, described above, might be ruptured. The process starts among those who question students' purpose in coming to Australia at all:

One of the reasons why they're coming here is globalization. You know, meeting people, networking from different counties...[In] this global world, you're going to need international experience. When I go to...the farewell ceremonies, where our director will come and speak, 
one thing [he says] is, "you'll be able to put this on your CV as you've had an international experience and that may make the difference when you are applying for a job back in Japan or back somewhere else."

(Anna, Teacher, university language centre, Major City, 2012)

If you're going to study with a class full of your own nationality, then why come here? Why not just do it in your own country? So you come here for more than what you can get back home. A part of that is a mixture of nationalities, where the common language is English...[The students want] the internationalization of themselves.

(Lisa, Director of Studies, university language centre, Regional City, 2012). These quotes speak of teachers who understand that students are, in part, seeking to acquire or hone interculturality with a view to acquiring the cultural, social, symbolic, and economic capital that this may confer in their home countries (Bourdieu, 1986). In order to do this, there is a need to problematize imagined 'authenticities' and help students move towards MacCannell's (2008: 334) "post-modern, post-structural, non-essentializing, hip version of culture as emergent, as constantly responding to challenge, changing and adapting”.

Some of the participants describe this kind of resistance:

[One of our teachers,] Su Ming, gosh I don't know where she's from but she's grown up in Australia. So if they're not aware about [how multicultural Australia is], they learn pretty quickly. I'm German, so I'm not Australian in pure terms...All our marketing material and all our brochures and all our orientations, all point to the fact that they're in Australia, which is multicultural. It's definitely not what they expect, but it's to be expected. [Describes an example, a student's complaint about a Japanese-heritage homestay family.] In this case it was a high school kid, the student. The high school teachers accompanying the student had to be re-educated a little bit as well and we said, "well this is Australia".

(Martin, Director of Studies, independent language centre, Regional City, 2012)

We've got European students who will say to me, "oh there's quite a lot of [Asian people in Australia]" and they'll do the slitty-eyed gesture. I'll say, "yeah, that's interesting, my wife's Japanese". They'll go, "oh right, yeah, sorry".

(Mark, Director of Studies, chain language centre, Regional City, 2012)

Europeans [students]...some of them we've had, refused to go into their class because there were too many Asian [students]. So what they're expecting is, they're expecting a European international language school. I've had students who have refused to go to a class because they don't like it. They'll make a slant-y eye gesture. They'll actually do that. I've had quite long and quite difficult discussions about needing to be culturally accepting...Teaching [them] that they are going to have to get to know people with an Asian background...But to what extent is that the fault of the marketing? If you look at our brochure there is not a percentage of Asian faces in any of the pictures. The faces are predominantly European and nice looking South Americans, all young people. So that expectation, I think, is partly the company's fault. If everything that you're shown shows 95 per cent of white faces and young people having a good time in Australia, then you get here and your class... 10 out of 15 people [are] Asian. They're Chinese, Japanese, Indonesian, Thai. But they [European students?] can't even distinguish between that. They just look 'Chinese' [to them].

(Amy, Director of Studies, chain language centre, State Capital, 2012)

These quotes evidence Directors of Studies' problematizing ideas about 'Australian' society, normalizing and pluralizing Asian-ness, and challenging some students' racism. Amy and Martin also highlight the role of marketing in shaping and managing students' expectations: whereas Amy's chain of language schools is a multinational (with glossy marketing materials and a global network of educational agents and marketing offices), Martin's centre is 
independent and he is a co-owner and, as such, he has much more control over how the centre, and English language teaching in Australia more generally, is marketed. As a result, he consciously showcases a 'multicultural' Australia to potential students. This difference illustrates an important point: although Amy's organization markets "predominantly European ... white faces", and this may sell language courses in a stereotypically imagined Australia, this also seem to set up and perpetuate stereotypical expectations that may subsequently cause problems. These problems are operational, in that part of the Director of Studies role may need to include ad hoc intercultural sensitivity training for students, as Mark and Amy describe. But the problems run much deeper: whereas students may hope to "internationalize themselves" through language study abroad, their experiences may, in fact, reify and reinforce pre-existing notions about putative "Asian" difference and an interculturality and Australian 'authenticity' that is strictly White (and photogenic).

To some extent, Directors of Studies may resist, as Amy explains, by hiring teachers who are rather more diverse than the marketing materials may suggest, including non-native-speaker teachers:

In my staff at the moment I've got 14 teachers. Only four of them are from [this city]. I've got two Brazilians, one Scottish, one English, one Irish, a South African and two from New Zealand. I also had a Canadian...Finnish...Norwegian...[and] Dutch teacher[s]. But I haven't had a Japanese-born or an Asian-born teacher. I have had Europeans and South Americans; and they've been part of the lovely cultural mix there hasn't been an issue.... Would it work the same if I had an Asian teacher who is Japanese and [a lot of] Japanese students? I don't think it would. I think [Japanese students] they're a bit harder to sell to in their expectations. I think they've come all this way and their expectation is to have someone who looks completely different [from them]. Yeah, if you looked at Marco [one of the Brazilian teachers], I mean he could be Brazilian, Italian, he could be Norwegian...He's European looking. I don't think it would work if I had a Korean looking or Japanese looking. [The students are buying] an image. Just a western image.

(Amy, Director of Studies, chain language centre, State Capital, 2012) I have written elsewhere about dichotomous discourses of difference that may frame East Asian students' expectations of 'Western' authenticity (Stanley, 2013: 46-51), and this is well documented in the literature on English language teaching in Japan (e.g., Rivers \& Ross, 2013). So although Amy's efforts to replicate Australian multiculturalism within the staffroom are laudable, some students' apparent conflation of 'Australianness' (and even inclass multiculturalism) with 'Whiteness' remains unchallenged. This is less obvious, and arguably less offensive, that the "slitty eyed" gestures made by the European students cited above, but racism it is nonetheless as it constructs 'authentic' Westernness as irreducibly white.

\section{Conclusion: Resisting 'The Known'}

Where, then, might we intervene in this problematic circle of certainty, to unravel a damning Mobius strip that constantly reinforces itself even as it twists the truth? My suggestion is that it is among the students themselves that change may best be initiated. At the moment, the teaching of 'culture' and 'interculturality', as discussed above, can be rather two-dimensional. The focus tends towards the superficial: 'food and festivals' and culture as context; this, paradoxically, actually reinforces discourses of essentialism, determinism and difference, that are also reinforced, problematically, in language school marketing. But students themselves, perhaps in an effort to 'internationalize themselves' are in fact grappling with these kinds of 'big' cultural issues, and it is my suggestion that classroom teaching of 'culture' might consider text analyses of this kind of conversation: 
Sabine: [Asian students] are just so different from us. I mean, it begins in the food how they, and their cloth[e]s.

Mathilde: It's, like, little things. Like I said to Emilie last week, I was really annoyed with my roommate. She's from Japan. She has a cold but she doesn't blow [her]

nose. She's like just sniffing and I'm, it's really irritating and Emilie said ... that it's a habit because in Japan it's rude to blow your nose. [So] for her, it's normal.

Sabine: $\quad$ Yes. For example when they eat they're always [chewing sound] and they make noises. So Sherry, she's my flatmate, yes. ... When I see what she eats she also always say, 'come and try', and I try because yes I want to taste, but I said, 'no, I can't eat it'. She eats eel, mix it all with her chopsticks. ... I think like sometimes they're like, not adult behaviour. Like childish, I think.

Emilie: $\quad$ So even how they walk because they don't move their feet they're choo-choochoo [gestures shuffling feet].... And they're not very sporty.

Sabine: $\quad$ They wear winter cloth[e]s, they don't wear shorts.

Mathilde: They don't want to get skin tanned....

Sabine: I think they have a lot of things about us to say as well. Because my roommate ... I think she is probably sometimes also annoyed by me and thinks maybe that I'm dirty or irritating and I have the same.

Emilie: $\quad$ Yes and one of the Asian boys, he's from Taiwan. He said to me and my friend he said, "you European girls you are so nice, you look so good, you don't have to put on [so] much makeup". I was like, "okay, thank you, but I have wear my makeup". He's like, "no don't wear makeup, you're so beautiful without it".

(Students, 'focus group', chain language centre, Regional City, 2012)

Between them, the students negotiate a series of surface-level indicators of (cultural) difference: food, clothing, make up, manners, hobbies, ways of walking, and notions of cleanliness. Intriguingly, as well as being able to delineate the 'ways' of the 'other' (problematically homogenized as 'Asian'), these European students also identify some of their own 'cultural' behaviours that the 'Asian' students may find troubling: to others, Europeans may be dirty, irritating, or overly made up. In a mixed nationality class, as is the norm in all the participant language centres, this kind of discussion could be the very focus of teaching of interculturality, with the intention of problematizing the surface-level indicators of difference and exposing unexpected similarities, commonalities, and shared humanity. One teacher comments:

[The students] are becoming more international, but I don't think there are many who actually trying to do that. I think that's just a by-product of what we do...They're looking for English, and hold a koala, and all that stuff...And they just haven't considered [anything else]. The Saudi with a Japanese friend. It just has not clicked ever in their existence. [in my class I look at culture.]...Next thing you know, "I think I'm going to move to Japan and study"...[There are] quite a few multicultural romances here, and [when they go home] I find that they're dating someone from a different culture in their home country. Whereas before they wouldn't have considered it. It's that exposure. [They become] broad-minded, yeah, and probably better people.

(James, Teacher, chain language school, Major City, 2012)

I would suggest, also, that as part of such a curriculum of interculturality development, the marketing materials used by language schools (and, indeed, Australian universities and other international education providers) might be studied and problematized for what they say, or do not say, about studying in Australia: students are uniquely placed to comment on their own lived experiences and the extent to which this is produced (or reproduced?) in and by such materials. A comparison might be made, for example, between the consciously 'multicultural' Australia portrayed in Martin's marketing materials and the airbrushed, 
European-looking 'Australia' produced by both Tourism Australia and the marketing divisions of language school chains like Amy's.

Students go to Australia, in part, to 'internationalise themselves', but when they get there they may find that pre-existing stereotypes are reified rather than challenged. This discredits the notion, all too often accepted in international education literature, that intercultural contact is sufficient for interculturality to develop. It isn't. Instead, it appears to be necessary to intervene and to mediate students' intercultural experiences, both of the host country and its realities (as compared to constructed 'authenticities') and also the intercultural experiences that they have with each other. This suggests a new way forward for the teaching of 'culture' in language education: teaching the interrogation of 'authenticity'. By addressing these complex, problematic issues in class, teachers can problematize the essentialist, realist views of culture that so often appear in English language textbooks. This would equip students with a vocabulary (and a taste) for resistance to the 'known'.

\section{Points to Ponder}

1. How do you react to Sabine, Mathilde, and Emilie's quotes? If you were teaching them, how might you engage them in developing their interculturality? Is this a valid goal of language learning in this context, do you think? Why/not?

2. Consider the various Directors of Studies' responses to the issue of teaching 'culture', whether through performing students' constructions of Australian authenticity back to them, managing students' expectations through marketing materials, or intervening and resisting by hiring multicultural teachers and providing ad hoc intercultural training. What would you do in this situation, and why?

3. This study was sparked by the comment "but my students like me!" To what extent is teacher popularity an indicator of teacher quality? How might this differ by context?

4. Emiko and Amy describe teachers that 'talk about his private story, it makes me closer' and that "gave personally". To what extent can (and should) teachers be their students' friends? Why is this important? What might be some tensions and issues?

5. Does learning about cultural others mean characterizing cultures for the purposes of teaching? If so, do we run the risk of essentialising and stereotyping cultural others? Against this background, how might we 'teach culture' as part of language education?

\section{References}

Ateljevic, I. and Doorne, S. (2005). Dialectics of authenticity: Performing 'exotic otherness' in a backpacker enclave of Dali, China. Journal of Tourism and Cultural Change, 3(1): 1-17.

Badone, E. and Roseman, S.R. (2004). Intersecting journeys: The anthropology of pilgrimage and tourism. Champaign, IL: University of Illinois Press.

Barrett, M. (2008). Intercultural competences: Reflections based on autobiography of intercultural encounters. Paper presented at the Council of Europe seminar on "Images of the 'Other' in history teaching: The role of history teaching institutions in the north and global south". Lisbon, Portugal.

Bourdieu, P. (1986). The forms of capital. In J.G. Richardson (Ed.), Handbook for theory and research for the sociology of education (pp. 241-258). New York, NY: 
Greenwood Press.

Bruner, E. (2005). Culture on tour: Ethnographies of travel. Chicago, IL: University of Chicago Press.

Butler, J. (1990). Gender trouble: Feminism and the subversion of identity. New York, NY: Routledge.

Cambridge ESOL (2003). CELTA syllabus and assessment guidelines. Cambridge: University of Cambridge ESOL Teaching Awards.

Charmaz, K. (2006). Constructing grounded theory. London: SAGE Publications.

Crang, P. (1997). Performing the tourist product. In C. Rojek and J. Urry (Eds.), Touring cultures: Transformations of travel and theory (pp. 137-154). London: Routledge.

Holliday, A. (2009). The role of culture in English language teaching: Key challenges. Language and Intercultural Communication, 9(3): 144-155.

Kontogeorgopoulos, N. (2003). Keeping up with the Joneses: Tourists, travellers, and the quest for cultural authenticity in southern Thailand. Tourist Studies, 3(2): 171-203.

Lewis, V. (2009). Peforming translatinidad: Miriam the Mexican transsexual reality show star and the tropicalization of difference in Anglo-Australian media. Sexualities, 12(2): 225-250.

Little, W.E. (2004). Mayas in the marketplace: Tourism, globalization, and cultural identity. Austin, TX: University of Texas Press.

MacCannell. (2008). Why it never really was about authenticity. Society, 45(4): 334-337.

Oakes, T. (2006). Get real! On being yourself and being a tourist. In C. Minca and T. Oakes (Eds.), Travels in paradox: Remapping tourism (pp. 229-250). Lanham, MD: Rowman \& Littlefield Publishers, Inc.

Pratt, M.L. (2004). Back yard with views. In A. Ross and K. Ross (Eds.), Anti-Americanism (pp. 32-46). New York, NY: New York University Press.

Rivers, D.J. and Ross, A.S. (2013). Idealized English teachers: The implicit influence of race in Japan. Journal of Language, Identity and Education, 12(5): 321-339.

Robinson, M. and Phipps, A. (2005). Dialectics of Authentication: Performing 'exotic otherness' in a backpacker enclave of Dali, China. Journal of Tourism and Cultural Change, 3(1): 1-17.

Rojek, C. and Urry, J. (Eds.). (1997). Touring cultures: Transformations of travel and theory. London: Routledge.

Stanley, P. (2013). A critical ethnography of 'Westerners' teaching English in China: Shanghaied in Shanghai. New York, NY: Routledge.

White, C.M. (2007). More authentic than thou: Authenticity and othering in Fiji tourism discourse. Tourist Studies, 7(1): 25-49.

Young, T.J., Sachdev, I. and Seedhouse, P. (2009). Teaching and learning culture on English language programmes: A critical review of the recent empirical literature. Innovation in Language Teaching and Learning, 3(2): 149-169. 